\title{
PERSEPSI DAN PARTISIPASI MASYARAKAT DALAM PELESTARIAN HUTAN RUMAH PELANGI SEBAGAI KAWASAN KONSERVASI (Studi Kasus Hutan Rumah Pelangi, Desa Teluk Bakung, Kecamatan Ambawang, Kabupaten Kubu Raya)
}

\author{
(Perception And Society Participation In The Forest Conservation Of Rumah Pelangi As \\ Conservation; Area A Case Study of Rumah Pelangi, Teluk Bakung Village, \\ Ambawang Subdistrict, Kubu Raya District)
}

\author{
Muhammad Syukur Wahyu Putra, Sofyan Zainal, Muhammad Idham \\ Fakultas Kehutanan Universitas Tanjungpura Jalan Imam Bonjol Pontianak 78124 \\ Email:putra182@gmail.com
}

\begin{abstract}
This research aims to determine the level of perception and society participation in forest conservation of Rumah Pelangi as conservation areas. Benefits of this research is to provide feedback for the manager and local authorities to managing the Rumah Pelangi for the sustainability of forest management in its area. The method used is descriptive while the data collection used a structured interview using a questionnaire. The number of respondents in the study were 76 respondents who are local residents and have at least 20 years old with minimum domicile in the are at least 3 years. Research result shows that public perceptions of the forest area in Rumah Pelangi is very low when averaged by the results of the two hamlets percentage did not achieve 50\%, and the level of result community participation is low category of all, are under $60 \%$. There is no correlation between perception and society participation in forest preservation of Rumah Pelangi. It is seen of the high number of society perception of Rumah Pelangi, however society participation in managing and protecting the region is very low.
\end{abstract}

Keyword: forest conservation, perception, participation, Rumah Pelangi, society

\section{PENDAHULUAN}

Rumah Pelangi merupakan salah satu kawasan konservasi di Provinsi Kalimantan Barat dengan luas 105 Ha. Hutan di Rumah Pelangi berada di Dusun Gunung Benuah, Desa Teluk Bakung, Kecamatan Sungai Ambawang, Kabupaten Kubu Raya. Rumah Pelangi mempunyai keanekaragaman hayati antara lain flora dan fauna yang dilindungi seperti tanaman endemik asli Kalimantan yaitu Kayu Ulin (Eusideroxylon zwageri). Ratusan jenis tanaman buah dan pepohonan asli Kalimantan dikembangkan di kawasan ini, antara lain pohon asam (18 jenis), bambu (15 jenis), pohon keras (14 jenis, misalnya belian, tapang, sengon, gaharu), dan berbagai jenis buah-buahan seperti rambutan, mangga, langsat, jambu, nangka, dan durian. Sejumlah bunga juga ditemukan seperti berbagai jenis anggrek dan kantung semar.

Keberadaan masyarakat sekitar Rumah Pelangi merupakan bagian yang tidak terpisahkan dari pengelolaan ekosistem Rumah Pelangi. Permasalahan yang kerap dialami oleh pengelola kawasan Rumah Pelangi sebagian besar terkait dengan masyarakat sekitar hutan. Oleh karena itu, penting untuk mengetahui 
persepsi dan partisipasi masyarakat disekitar yang menerima manfaat langsung dalam pemanfaatan sumberdaya hayati hutan. Kawasan hutan Rumah Pelangi merupakan salah satu kawasan hutan yang jaraknya sangat dekat dengan ibu kota Propinsi Kalimantan Barat yaitu kota Pontianak. Kondisi seperti ini menjadikan hutan Rumah Pelangi cukup potensial untuk tujuan rekreasi, penelitian, pelatihan, pendidikan lingkungan, serta kegiatan alam lainnya. Adanya penebangan kayu bulat kecil (kbk) disekitarnya dikhawatirkan akan menimbulkan perambahan hutan sampai ke dalam kawasan hutan Rumah Pelangi yang salah satu dampaknya adalah hilangnya vegetasi hutan dan plasma nutfah. Kepedulian masyarakat yang berada disekitar kawasan hutan Rumah Pelangi akan memberikan jaminan terhadap eksistensi di masa yang akan datang serta memberikan lebih banyak manfaat untuk menunjang kebutuhan dasar masyarakat sekitar.

Penelitian bertujuan untuk mengetahui persepsi dan partisipasi masyarakat Desa Teluk Bakung dalam pelestarian hutan Rumah Pelangi sebagai kawasan konservasi dan mengetahui peran masyarakat dalam pelestarian kawasan hutan Rumah Pelangi. Manfaat dari penelitian ini adalah untuk memberikan masukan kepada kepastoran OFM CAP Bukit Tunggal dan Pemerintah Kabupaten Kubu Raya dalam membuat program yang melibatkan masyarakat sebagai peran utama sehingga pengelolaan kawasan hutan Rumah Pelangi menjadi lebih baik dimasa yang akan datang.

\section{METODOLOGI PENELITIAN}

Penelitian dilakukan di Dusun Enggang Raya dan Dusun Gunung Benuah Desa Teluk Bakung, Kecamatan Sungai Ambawang, Kabupaten Kubu Raya dengan pegambilan sampel selama dua minggu efektif di lapangan. Teknik pengambilan sampel menggunakan teknik purposive sampling yaitu mengambil sampel yang dilakukan secara sengaja serta berdasarkan tujuan tertentu. Untuk menetukan besarnya ukuran sampel responden dalam penelitian ini dihitung dengan rumus Slovin dengan berdasarkan perhitungan tersebut, maka besar sempel responden yang diambil dari jumlah populasi (kepala keluarga) $327 \mathrm{KK}$ dengan tingkat kesalahan $10 \%$ yaitu sebesar 76 KK. Penelitian ini bersifat deskriptif dengan wawancara terstruktur menggunakan kuesioner. Analisis data tingkat persepsi berdasarkan jumlah persentasi responden yang menjawab setiap pertanyaan dengan pilihan jawaban sangat tahu, tahu, cukup tahu, dan tidak tahu kemudian dianalisis dengan tabulasi data. Pengelompokan tingkat partisipasi masyarakat didasarkan atas tiga kategori yaitu : Partisipasi rendah, jika skor yang diperoleh $<60 \%$ Partisipasi sedang, jika skor yang diperoleh $\geq 60 \%-\leq 70 \%$, Partisipasi tinggi, jika skor yang diperoleh > $70 \%$ (Nugraha, 2007).

\section{HASIL DAN PEMBAHASAN}

Berdasarkan hasil penelitian, sebagian besar responden yang menyatakan tahu mengemukakan persepsi secara beragam. Persepsi responden mengenai apa itu hutan adalah sebagai berikut: Hutan merupakan sumber daya kayu yang harus dimanfaatkan, hutan merupakan sumber 
pencaharian, hutan merupakan tempat berladang, hutan sebagai tempat mencari obat-obatan dan kebutuhan upacara adat, hutan tempat berburu, hutan tempat sumber penghidupan. Pengetahuan masyarakat mengenai Rumah Pelangi adalah hampir semua masyarakat menjawab tahu baik itu posisi maupun fungsi dari Rumah Pelangi itu sendiri. Keragaman persepsi responden menunjukkan adanya keragaman pengetahuan dan pemahaman masyarakat mengenai hutan bahkan juga terkait dengan adanya perbedaan aktifitas masyarakat dalam kehidupannya seharihari. Masyarakat yang aktifitasnya tergantung dengan hutan cenderung mempersepsikan hutan sebagai sumber ekonomi atau mata pencaharian dengan mengabaikan peran dan fungsi hutan secara ekologis misalnya mengatur tata air.

Persepsi responden dengan sepuluh pertanyaan dengan 37 responden yang diajukan jawabannya sangat bervariasi, yang mengetahui apa itu hutan dan dapat menjelaskan secara mendetail, dikategorikan sangat tahu dengan jumlah $14(37,84 \%)$ responden, sedangkan yang mengetahui hutan tetapi menjelaskan tidak spesifik dikategorikan tahu dengan jumlah 17 (45,95\%), sedangkan yang mengetahui hutan dan tidak dapat menjelaskan sesuai dengan pengertiannya dikategorikan cukup tahu dengan jumlah 6 (16,22), dan yang tidak mengetahui dan tidak dapat menjelaskan pengertian hutan dikategorikan tidak tahu tidak ada. Sedangkan pengetahui masyarakat mengenai Rumah Pelangi yaitu sangat tahu sebanyak 19 (51,35\%), Tahu sebanyak 15 (40,54\%), cukup tahu sebanyak $3(8,11 \%)$, dan tidak tahu tidak ada yang menjawab atau tidak memiliki persentasi. Terkait keberadaan kawasan hutan Rumah Pelangi yang menjawab sangat tahu sebanyak 20 (54,05\%), menjawab tahu sebanyak 14 (37,84\%), cukup tahu sebanyak $3(8,11)$ dan tidak tahu tidak ada yang menjawab.

Manfaat dari keberadaan kawasan Rumah Pelangi bagi masyarakat yang menjawab sangat tahu sebanyak 4 $(10,81 \%)$, mejawab tahu $4(10,81 \%)$, cukup tahu $12(32,43 \%)$ dan tidak tahu sebanyak 17 (45,95\%). Manfaat dari keberadaan kawasan Rumah Pelangi bagi lingkungan dengan hasil sangat tahu 3 $(8,11 \%)$, tahu $8(21,62 \%)$, cukup tahu 10 $(27,03 \%)$ dan tidak tahu 16 (43,24\%). Pengetahuan tentang keterlibatan berbagai pihak dalam pengelolaan kawasan hutan Rumah Pelangi yang menjawab sangat tahu sebanyak $4(10,81 \%)$, tahu $3(8,11 \%)$, cukup tahu 11(29,73\%), dan tidak tahu sebanyak $13(35,14 \%)$. Pertanyaan yang menyangkut tentang apa saja yang terdapat didalam kawasan hutan Rumah Pelangi yang menjawab sangat tahu sebanyak 5 $(13,51 \%)$, tahu 5 (13,52\%), cukup tahu 14 $(37,84)$, dan tidak tahu $13(35,14 \%)$.

Pertanyaan nomor delapan mengenai apa saja yang sering dimanfaatkan masyarakat didalam kawasan hutan Rumah Pelangi yang menjawab sangat tahu $3(8,11 \%)$, tahu $4(10,81 \%)$, cukup tahu $11(29,73 \%)$, dan tidak tahu sebanyak 19 (51,35\%). Pengetahuan masyarakat tentang kawasan Rumah Pelangi sebagai lokasi dan sarana rekreasi yang menjawab sangat tahu sebanyak $6(16,22 \%)$, tahu 4 $(10,81 \%)$, cukup tahu $8(21,62 \%)$ dan tidak tahu sebanyak 19 (51, 35\%). 
Pertanyaan terakhir tentang pemanfaatan atau yang bermanfaat dari kawasan Rumah Pelangi yang menjawab sangat tahu sebanyak $4(10,81 \%)$, tahu $3(8,11 \%)$, cukup tahu $16(43,24 \%)$ dan tidak tahu sebanyak 14 (37,84\%). Persentase mengenai persepsi masyarakat Dusun Enggang Raya Desa Teluk Bakung, Kecamatan Sungai Ambawang Kabupaten Kubu Raya terhadap keberadaan Rumah Pelangi sebagai kawasan hutan konservasi disajikan pada Grafik 1.

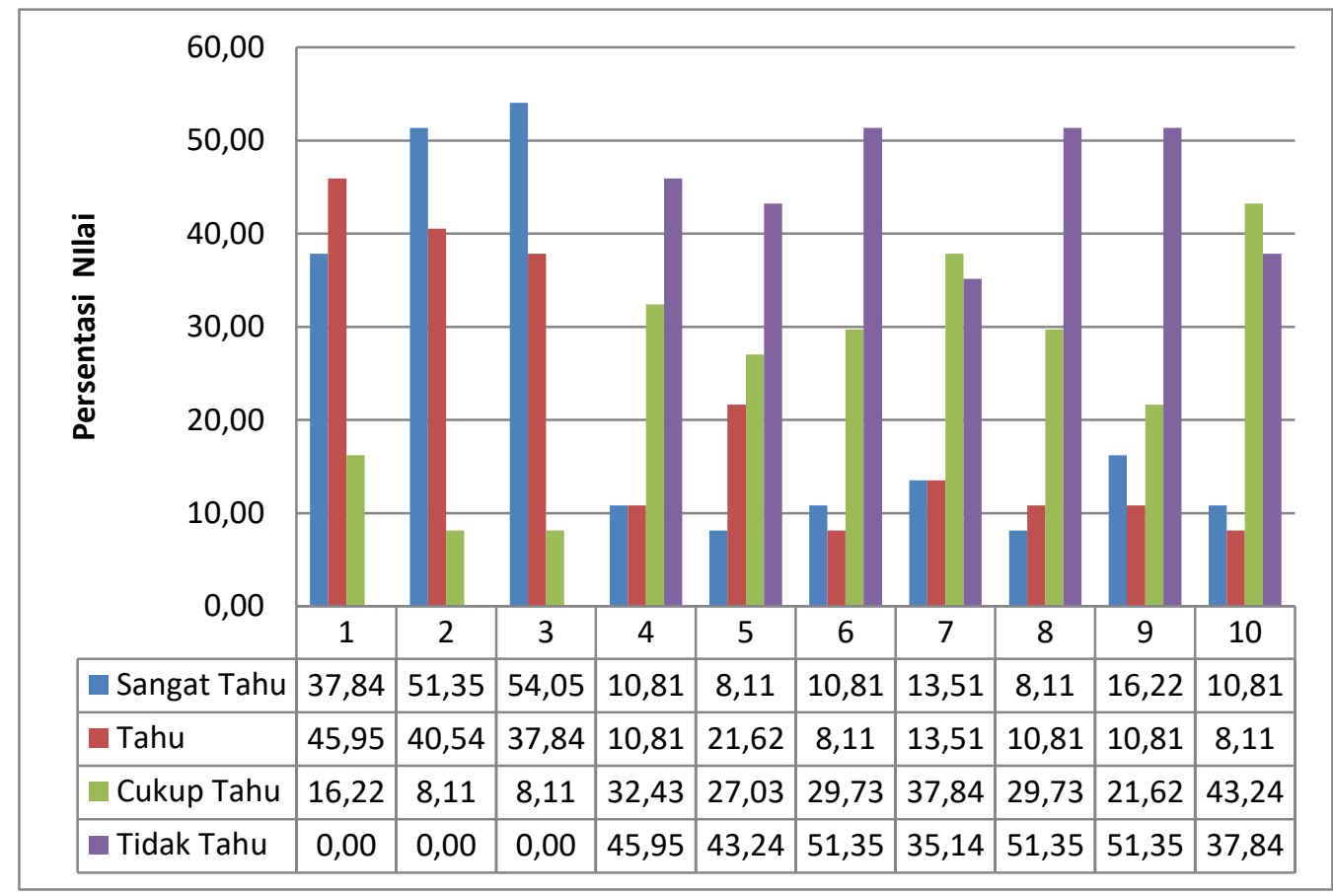

Grafik 1. Persepsi Masyarakat Dusun Enggang Raya Desa Teluk Bakung, Kecamatan Sungai Ambawang Kabupaten Kubu Raya Terhadap Keberadaan Hutan Rumah Pelangi Sebagai Kawasan Konservasi (Society Perception of Dusun Enggang Raya Teluk Bakung village, Sungai Ambawang Sub District, Kubu Raya Regency In Forest Preservation of Rumah Pelangi as Conservation Area)

Persepsi Responden di Dusun Gunung Benuah Desa Teluk Bakung Kecamatan sungai Ambawang Kabupaten Kubu Raya dengan sepuluh pertanyaan dan 39 responden yang diajukan jawabannya sangat bervariasi, yang mengetaui apa itu hutan dan dapat menjelaskan secara mendetail, dikategorikan sangat tahu dengan jumlah 17 orang $(43,59 \%)$ responden, sedangkan yang mengetahui hutan tetapi menjelaskan tidak spesifik dikategorikan tahu dengan jumlah 15 orang $(38,46 \%)$, sedangkan yang mengetahui hutan dan tidak dapat menjelaskan sesuai dengan pengertiannya dikategorikan cukup tahu 4 orang $(10,26 \%)$, dan yang tidak mengetahui dan tidak dapat menjelaskan pengertian hutan dikategorikan tidak tahu sebanyak 3 orang $(7,69 \%)$. 
Pengetahuan masyarakat mengenai Rumah Pelangi yaitu sangat tahu sebanyak 14 orang $(35,90 \%)$, Tahu 6 orang $(15,38 \%)$, cukup tahu 15 orang $(38,46 \%)$, dan tidak tahu sebanyak 4 orang $(10,26 \%)$. Terkait keberadaan kawasan hutan Rumah Pelangi yang menjawab sangat tahu sebanyak 14 orang (35,9\%), Tahu 10 orang $(25,64 \%)$, cukup tahu 9 orang $(20,08 \%)$ dan tidak tahu sebanyak 6 orang $(15,38 \%)$. Manfaat dari keberadaan kawasan rumah pelangi bagi masyarakat yang menjawab sangat tahu sebanyak 1 orang $(2,56 \%)$, tahu 5 orang $(12,82 \%)$, cukup tahu 7 orang $(17,95 \%)$ dan tidak tahu sebanyak 26 orang $(66,27 \%)$. Manfaat dari keberadaan kawasan rumah pelangi bagi lingkungan dengan hasil sangat tahu sebanyak 1 orang $(2,56 \%)$, tahu 2 orang $(5,13 \%)$, cukup tahu 11 orang $(28,21 \%)$ dan tidak tahu sebanyak 25 orang $(64,10 \%)$. Pengetahuan tentang keterlibatan berbagai pihak dalam pengelolaan kawasan hutan Rumah Pelangi yang menjawab sangat tahu tidak ada yang menjawab atau memiliki nilai 0 $(0,00 \%)$, tahu $1(2,56 \%)$, cukup tahu 12 $(30,77 \%)$, dan tidak tahu sebanyak 26 $(66,67 \%)$. Pertanyaan yang menyangkut tentang apa saja yang terdapat didalam kawasan hutan Rumah Pelangi yang menjawab sangat tahu sebanyak 1 (2,56\%), tahu 2 (5,13\%), cukup tahu 12 $(30,77)$, dan tidak tahu sebanyak 24 $(61,54 \%)$.

Pertanyaan nomor delapan mengenai apa saja yang sering dimanfaatkan masyarakat didalam kawasan hutan Rumah Pelangi yang menjawab sangat tahu tidak ada yang mengetahui atau memiliki nilai 0 $(0,00 \%)$, tahu memiliki nilai $0(0,00 \%)$, cukup tahu $12(30,77 \%)$, dan tidak tahu sebanyak 27 (69,23\%). Pengetahuan masyarakat tentang kawasan Rumah Pelangi sebagai lokasi dan sarana rekreasi yang menjawab sangat tahu memiliki nilai $0 \quad(0,00 \%)$, tahu 1 $(2,56 \%)$, cukup tahu $4(10,26 \%)$ dan tidak tahu sebanyak 34 (87, 18\%). Pertanyaan terakhir tentang pemanfaatan dan yang bermanfaat dari kawasan rumah pelangi adalah yang menjawab sangat tahu dengan nilai 0 $(0,00 \%)$, tahu $2(5,13 \%)$, cukup tahu 11 $(28,21 \%)$ dan tidak tahu sebanyak 26 $(66,67 \%)$. Persentase mengenai persepsi masyarakat Dusun Gunung Benuah, Desa Teluk Bakung, Kecamatan Sungai Ambawang Kabupaten Kubu Raya disajikan pada Grafik 2. 


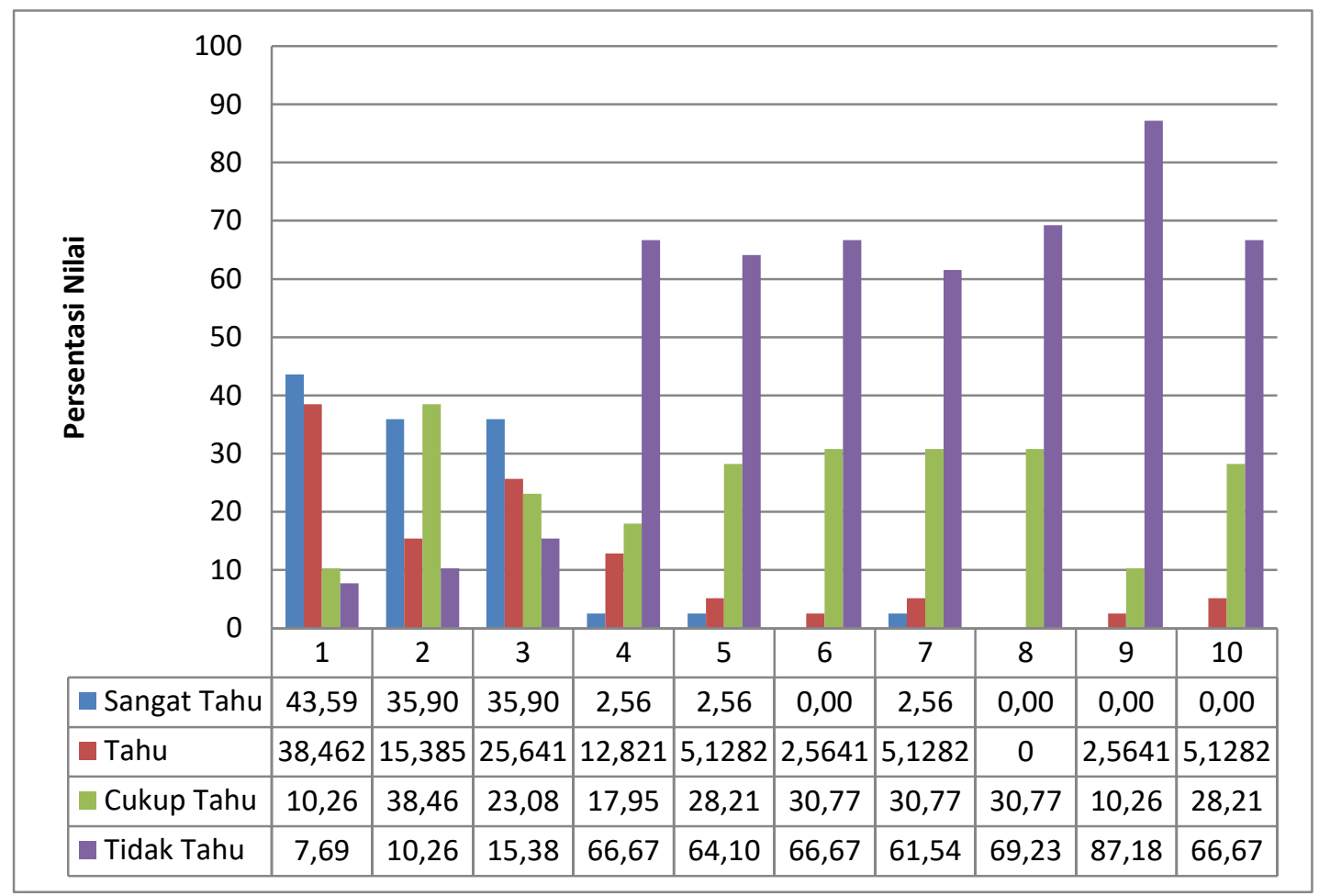

Grafik 2. Persepsi Masyarakat Dusun Gunung Benuah Desa Teluk Bakung, Kecamatan Sungai Ambawang Kabupaten Kubu Raya Terhadap Keberadaan Hutan Rumah Pelangi Sebagai Kawasan Konservasi (Society Perception of Dusun Gunung Benuah Teluk Bakung village, Sungai Ambawang Sub District, Kubu Raya Regency In Forest Preservation of Rumah Pelangi as Conservation Area)

Hasil analisis kuantifikasi partisipasi masyarakat berdasarkan responden 37 orang dapat dijelaskan sebagai berikut (Grafik 3). Ketika masyarakat melakukan aktivitas dikawasan hutan Rumah Pelangi yang menyatakan sangat sering sebanyak $2,70 \%$, yang menyatakan sangat sering $2,70 \%$, jarang $13,51 \%$ dan tidak pernah $81,08 \%$. Menyangkut seberapa banyak masyarakat melakukan aktivitas di dalam kawasan hutan Rumah Pelangi yang menjawab sangat sering $2,70 \%$, sering $1,70 \%$, jarang $13,51 \%$ dan tidak pernah $81,08 \%$ Keterlibatan masyarakat secara langsung dalam pengelolaan kawasan hutan Rumah Pelangi yang menjawab sangat sering $2,70 \%$, sering tidak ada yang menjawab atau $0 \%$, jarang $8,11 \%$ dan tidak pernah $89,19 \%$. Keterlibatan masyarakat dalam memberikan masukkan dalam pengelolaan kawasan hutan Rumah Pelangi yang menjawab sangat sering $2,70 \%$, sering tidak ada yang menjawab sama sekali atau $0 \%$, jarang sebanyak $2,70 \%$ dan tidak pernah 94,59\%. Pertanyaan terakhir terkait partisipasi masyarakat dalam menjaga kawasan hutan Rumah Pelangi sebagai kawasan konservasi yang menjawab sering $2,70 \%$, sering tidak ada yang menjawab 
atau $0 \%$, jarang sebanyak $2,70 \%$ dan tidak pernah $94,59 \%$.

Hasil analisis kuantifikasi partisipasi masyarakat berdasarkan responden 39 orang dapat dijelaskan sebagai berikut (Grafik 4). Ketika masyarakat melakukan aktivitas dikawasan hutan Rumah Pelangi yang menyatakan sangat sering sebanyak $0,00 \%$, yang menyatakan sering $2,56 \%$, jarang 30,77\% dan tidak pernah 66,67 $\%$. Menyangkut seberapa banyak masyarakat melakukan aktivitas didalam kawasan hutan Rumah Pelangi yang menjawab sangat sering 2,56\%, sering $0,00 \%$, jarang $30,77 \%$ dan tidak pernah $\quad 66,67 \%$ Keterlibatan masyarakat secara langsung dalam pengelolaan kawasan hutan Rumah Pelangi yang menjawab sangat sering $2,56 \%$, sering tidak ada yang menjawab atau $0 \%$, jarang $23,08 \%$ dan tidak pernah $74,36 \%$. Keterlibatan masyarakat dalam memberikan masukkan dalam pengelolaan kawasan hutan Rumah Pelangi yang menjawab sangat sering $2,56 \%$, sering tidak ada yang menjawab sama sekali atau $0 \%$, jarang sebanyak 2,56\% dan tidak pernah 94,87\%. Pertanyaan terakhir terkait partisipasi masyarakat dalam menjaga kawasan hutan Rumah Pelangi sebagai kawasan konservasi yang menjawab sering $0,00 \%$, sering $2,56 \%$, jarang sebanyak 210,26\% dan tidak pernah $87,18 \%$.

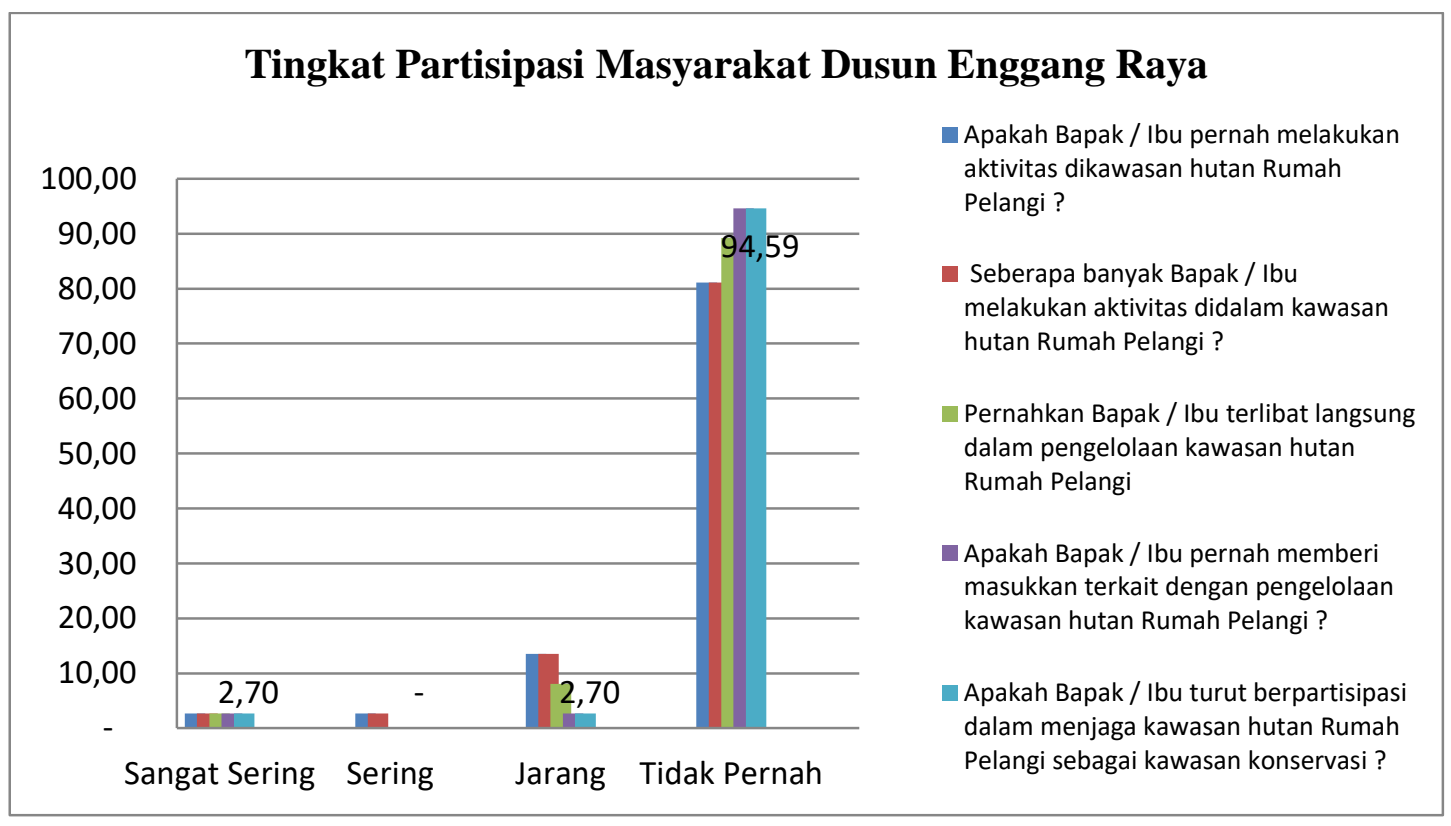

Grafik 3. Tingkat Partisipasi Masyarakat Dusun Enggang Raya Desa Teluk Bakung, Kecamatan Sungai Ambawang Kabupaten Kubu Raya di Kawasan Hutan Rumah Pelangi (Society Participation Rate of Dusun Enggang Raya Teluk Bakung village, Sungai Ambawang Sub District, Kubu Raya Regency In Forest Preservation of Rumah Pelangi) 
JURNAL TENGKAWANG (2018)

Vol. 8 (1) : 26 - 37

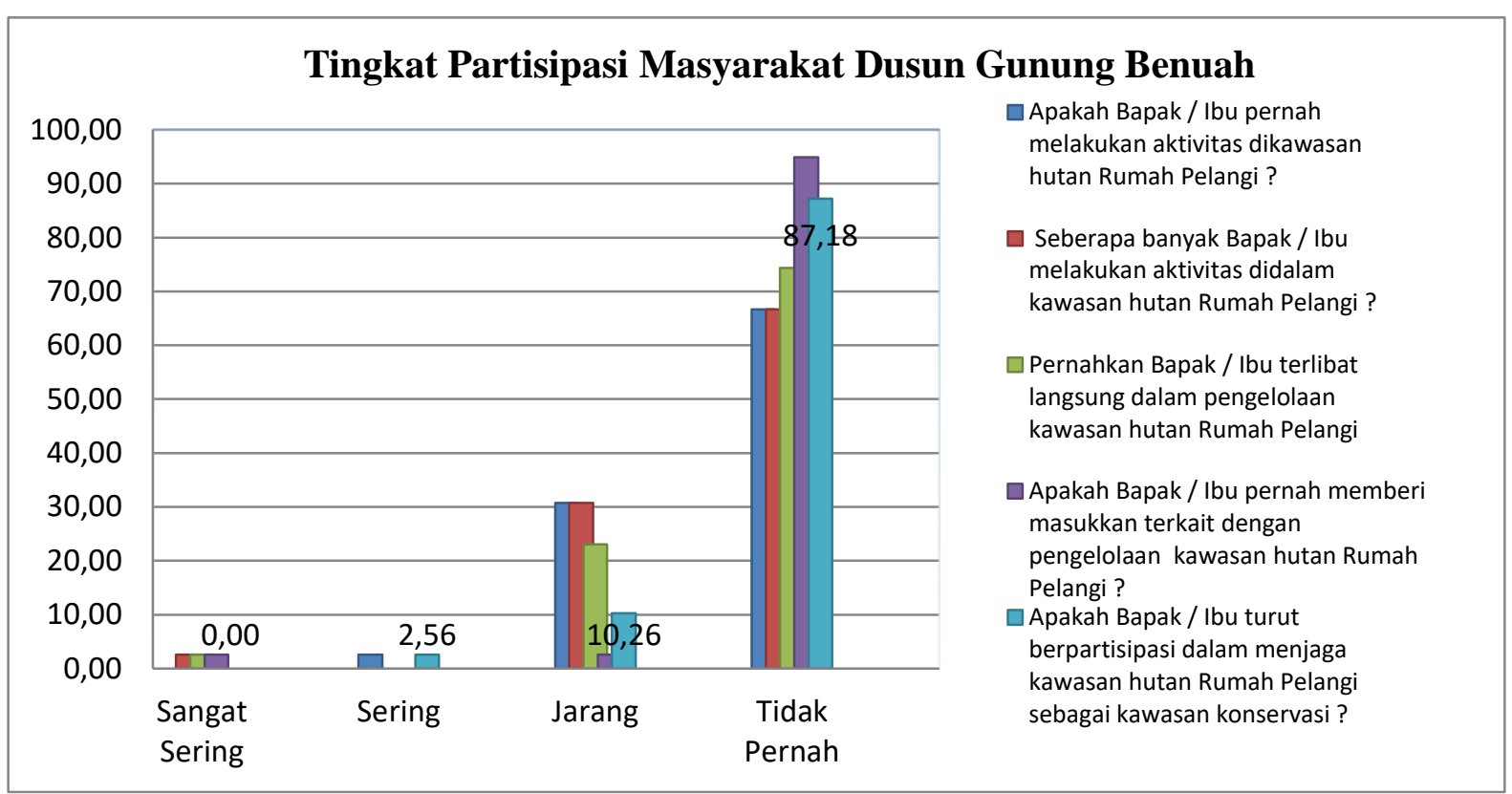

Grafik 4. Tingkat Partisipasi Masyarakat Dusun Gunung Benuah Desa Teluk Bakung, Kecamatan Sungai Ambawang Kabupaten Kubu Raya di Kawasan Hutan Rumah Pelangi (Society Participation Rate of Dusun Gunung Benuah Teluk Bakung village, Sungai Ambawang Sub District, Kubu Raya Regency In Forest Preservation of Rumah Pelangi)

Analisis data tingkat partisipasi didasarkan pada pengukuran variabel komponen partisipasi terhadap pengelolaan yang terdiri dari empat skala, yakni skor 4 untuk sering, skor 3 cukup sering, skor 2 jarang dan skor 1 tidak pernah. Analisis dilakukan dengan menggunakan analisis tabulasi dengan membandingkan jumlah skor rata-rata dan didapatlah dengan skor yang ditampilkan pada Tabel 1. 
Tabel 1. Tingkat Partisipasi Masyarakat Dusun Gunung Benuah dan Dusun Enggang Raya dalam Pelestarian Kawasan Hutan Rumah Pelangi Sebagai Kawasan Konservasi (Society Participation Rate of Dusun Gunung Benuah and Dusun Enggang Raya in Forest Area Preservation of Rumah Pelangi as Conservation Area)

\begin{tabular}{|c|c|c|c|c|c|}
\hline & Uraian & $\begin{array}{l}\text { Skore } \\
\text { Didapat } \\
\text { (SrD) }\end{array}$ & $\begin{array}{l}\text { Skor } \\
\text { Ideal } \\
\text { (SrL) }\end{array}$ & $\begin{array}{c}\text { Tingkat } \\
\text { Partisipasi }\end{array}$ & $\begin{array}{c}\text { Kategori } \\
\text { Tingkat } \\
\text { Partisipasi }\end{array}$ \\
\hline 1 & $\begin{array}{l}\text { Apakah Bapak / Ibu pernah } \\
\text { melakukan aktivitas dikawasan } \\
\text { hutan Rumah Pelangi ? }\end{array}$ & 45 & 200 & 22,50 & Rendah \\
\hline 2 & $\begin{array}{l}\text { Seberapa banyak Bapak / Ibu } \\
\text { melakukan aktivitas didalam } \\
\text { kawasan hutan Rumah Pelangi? }\end{array}$ & 45,5 & 200 & 22,75 & Rendah \\
\hline 3 & $\begin{array}{l}\text { Pernahkan Bapak / Ibu terlibat } \\
\text { langsung dalam pengelolaan } \\
\text { kawasan hutan Rumah Pelangi }\end{array}$ & 40 & 200 & 20,00 & Rendah \\
\hline 4 & $\begin{array}{l}\text { Apakah Bapak / Ibu pernah } \\
\text { memberi masukkan terkait dengan } \\
\text { pengelolaan kawasan hutan } \\
\text { Rumah Pelangi? }\end{array}$ & 36 & 200 & 18,00 & Rendah \\
\hline 5 & $\begin{array}{l}\text { Apakah Bapak / Ibu turut } \\
\text { berpartisipasi dalam menjaga } \\
\text { kawasan hutan Rumah Pelangi } \\
\text { sebagai kawasan konservasi? }\end{array}$ & 33 & 200 & 16,50 & Rendah \\
\hline
\end{tabular}

Persepsi masyarakat tentang Rumah Pelangi sangat rendah, namun berdasarkan fungsinya masyarakat tidak banyak yang tahu apa manfaat dan fungsi dari keberadaan kawasan hutan Rumah Pelangi tersebut. Berdasarkan hasil penelitian ini bahwa peran serta masyarakat didalam pelestarian hutan Rumah Pelangi sangatlah minim sekali. Dusun Enggang Raya dari 37 responden yang diwawancarai hanya 4 orang yang mengetahui manfaat Rumah Pelangi atau sebesar 10, $81 \%$. Sementara masyarakat yang mengetahui siapa saja yang terlibat didalam pengelolaan kawasan Rumah Pelangi ada 4 orang dengan persentase 10,81\%. Dusun Gunung Benuah dari hasil penelitian memperoleh hasil yaitu persepsi masyarakat tentang Rumah Pelangi sangat rendah yaitu hanya 14 orang yang menjawab sangat tepat atau $35,90 \%$, sementara responden yang menjawab siapa saja yang terlibat didalam pengelolaan Rumah Pelangi yang menjawab benar tidak ada sama sekali, hal ini menyatakan bahwa hubungan persepsi dan partisipasi sangat erat, dimana persepsi masyarakat memiliki nilai yang sangat rendah sementara partisipasinya dalam pengelolaan kawasan sangatlah minim atau buruk. Peran masyarakat tidak begitu signifikan dalam pengelolaan hutan Rumah Pelangi sebagai kawasan konservasi, hal ini dibuktikan dengan rendahnya nilai persepsi dan partisipasi masyarakat dalam pengelolaan 
kawasan. Semua ini berfaktor kepada tidak meratanya tingkat pendidikan dan pengetahuan masyarakat serta yang paling memungkinkan bahwa tidak semua masyarakat setempat memperoleh keuntungan dari keberadaan kawasan hutan Rumah Pelangi. Menurut Nugraha (2007) pengelompokan tingkat partisipasi masyarakat didasarkan atas tiga kategori yaitu : Partisipasi rendah, jika skor yang diperoleh < $60 \%$ Partisipasi sedang, jika skor yang diperoleh $\geq 60$ $\%-\leq 70 \%$, Partisipasi tinggi, jika skor yang diperoleh $>70 \%$.



Grafik 5. Tingkat Partisipasi Masyarakat Dalam Pelestarian Hutan Rumah Pelangi Sebagai Kawasan Hutan Konservasi (Levels Society Participation In Forest Preservation of Rumah Pelangi As Conservation Forest Area)

Berdasarkan hasil penelitian dan dihubungkan dengan Tipologi Tangga Partisipasi Arnstein (1969) bahwa partisipasi masyarakat di sekitar kawasan hutan Rumah Pelangi yaitu di dusun Enggang Raya dan dusun Gunung Benuah masuk dalam urutan tangga nomor 2 dan 3 yaitu terapi dan informasi. Adapun penjelasan dari urutan tangga tipologi tersebut adalah sebagai berikut :

1. Manipulasi (manipulation). Pada tangga partisipasi ini bisa diartikan relatif tidak ada komunikasi apalagi dialog; tujuan sebenarnya bukan untuk melibatkan masyarakat dalam perencanaan dan pelaksanaan program tapi untuk mendidik atau "menyembuhkan" partisipan (masyarakat tidak tahu sama sekali terhadap tujuan, tapi hadir dalam forum).

2. Terapi (therapy) pada level ini telah ada komunikasi namun bersifat terbatas. Inisiatif datang dari pemerintah dan hanya satu arah. Tangga ketiga, keempat dan kelima 
dikategorikan sebagai derajat tokenisme dimana peran serta masyarakat diberikan kesempatan untuk berpendapat dan didengar pendapatnya, tapi mereka tidak memiliki kemampuan untuk mendapatkan jaminan bahwa pandangan mereka akan dipertimbangkan oleh pemegang keputusan. Peran serta pada jenjang ini memiliki kemungkinan yang sangat kecil untuk menghasilkan perubahan dalam masyarakat

Hubungan persepsi dan partisipasi masyarakat dalam pelestarian hutan kawasan Rumah Pelangi sebagai kawasan konservasi berbanding terbalik dimana persepsi menunjukkan bahwa tingkat pengetahuan masyarakat mengenai Rumah Pelangi cukup tinggi dengan angka ratarata $45 \%$, namun dilihat dari segi partisipasi masyarakat sangat kurang dengan nilai yang rendah yaitu angka 18$20 \%$ artinya nilai ini dibawah $60 \%$ dan dikategorikan rendah (Nugraha, 2007). Hal ini dipengaruhi beberapa faktor antara lain tingkat pendidikan, ekonomi, dan pengetahuan masyarakat tentang hutan. Roslinda (2008) lebih lanjut menjelaskan bahwa pengetahuan lokal tidak tersebar secara merata dalam masyarakat, sikap setiap individu dalam menyimpan pengetahuan tradisional dan kemampuan dalam menghasilkan pengetahuan baru juga berbeda. Pengelolaan hutan sepenuhnya diserahkan kepada masyarakat lokal untuk memanfaatkn sumber daya hutan sesuai dengan kebutuhan, kemampuan, dan pengetahuan yang dimiliki dalam jangka waktu tertentu. Dengan demikian, masyarakat merasa ikut bertanggung jawab dalam pelestarian hutan dengan fungsi, status, dan kepemilikan hutan yang ada, Pengetahuan yang diperoleh secara turun temurun, khususnya berkaitan dengan pelestarian hutan.

Menurut pendapat Sumardi dkk (1997) pola pikir masyarakat pedesaan yang tinggal dikawasan hutan yang umumnya mempunyai pekerjaan di bidang pertanian memperlihatkan hubungan yang erat dengan lingkungan hidupnya. Disamping itu masyarakat dikawasan hutan umumnya mengenai sikap dan pola berfikir serta bertindak masih berpegang teguh pada norma, adat serta tradisi yang diwariskan secara turun-temurun, hal ini tidak saja dalam kaitan dengan kehidupan bermasyarakat, namun juga nampak dari prilakunya dalam menghadapi lingkungan hidup atau hutan. Masyarakat dengan tingkat pengetahuan tinggi cendrung memiliki partisipasi yang positif, kaitannya dengan masyarakat yang memiliki pendidikan formal atau rendah, tidak menutup kemungkinan memiliki pengetahuan yang tinggi, karena masyarakat yang memiliki tingkat pengetahuan tinggi telah sejak lama mengetahui bahaya yang dapat ditimbulkan apabila ditiadakannya pelestarikan hutan adat yang ada. Pengetahuan yang diterima seseorang tidak hanya berasal dari pendidikan formal saja tetapi juga dipengaruhi oleh besarnya informasi yang diterima seseorang, begitupula dengan masyarakat yang dikategorikan pengetahuan sedang cenderung memiliki partisipasi yang positif, karena masyarakat sadar dari manfaat pelestarian hutan adat yang ada. 


\section{PENUTUP}

Kesimpulan

1. Persepsi masyarakat Dusun Enggang Raya dalam pelestarian kawasan hutan Rumah Pelangi sebagai kawasan konservasi sangatlah rendah begitu juga dengan persepsi masyarakat di dusun Gunung Benuah.

2. Partisipasi masyarakat sekitar dalam melestarikan hutan Rumah Pelangi sebagai kawasan konservasi mempunyai tingkat partisipasi yang rendah yaitu dibawah $60 \%$.

3. Peran serta masyarakat dalam pelestarian hutan Rumah Pelangi sebagai kawasan konservasi masih sangat rendah, hal ini berhubungan dengan tingkat persepsi dan partisipasi masyarakat yang sangat rendah.

4. Tidak terdapat hubungan antara Persepsi dengan Partisipasi masyarakat sekitar hutan diantara kedua dusun tersebut dalam melestarikan Rumah Pelangi sebagai kawasan konservasi.
Saran

1. Dari hasil penelitian menunjukkan bahwa hutan Rumah Pelangi masih dimanfaatkan masyarakat setempat maka dari itu kelestarian dan pemanfaatannya harus memperhatikan aspek keberlanjutan.

2. Perlunya sosialisasi dan kolaborasi dari berbagai pihak terkait pengelolaan hutan Rumah Pelangi untuk masyarakat dan lingkungan.

\section{DAFTAR PUSTAKA}

Arnstein S.R, 1969. A Ladder of Citizen Participation. JAIP, Vol.35. No. 4, Juli 1969

Nugraha, AP. 2007. Partisipasi Masyarakat Pada Kegiatan Reklamasi Areal Bekas Tambang di Kecamatan Karang Intan. Fakultas Kehutanan. Universitas Lambung Mangkurat. Banjarbaru.

Roslinda, E. 2008. Hutan Kemasyarakatan. Alfabeta. Bandung

Sumardi, Sukarjo, Sukari, Murtolo, Muryantoro. 1997. Peranan nilai budaya daerah dalam upaya pelestarian lingkungan hidup Daerah Istimewa Yogyakarta. Yogyakarta 